\title{
International Migrations: Some Comparisons and Lessons for the European Union
}

\author{
Giovanni Peri (University of California, Davis and NBER) ${ }^{1}$ \\ This version: December 2005
}

\begin{abstract}
The revival of international migration in the last fifteen years has spurred economists to more systematically study their determinants and consequences. This contribution expands the existing literature in two directions. First we focus on the European Union as a whole and compare it to the US and other countries with net immigration (Canada, Australia and Switzerland). In so doing we establish some important facts about their capacity to attract migrant, and to foster internal migration across countries. Second, we analyze more systematically the causes and consequences of international migration of workers with different educational levels. We use a recent data set based on census information on natives and foreign born in 28 OECD countries for the year 2000. Four important facts emerge: 1) The European Union, far from acting like an integrated labor market (such as the US), exhibits low levels of cross-country internal mobility (for all skill levels) even compared to other OECD countries. 2) The European Union lags far behind the US and other immigration countries (Canada, Australia, Switzerland) in its ability to attract immigrants from outside (for all skills levels). 3) While typical immigration economies attract international migrants whose schooling achievements are complementary to those of natives, thus increasing wages for a majority of their natives, the EU attracts immigrants whose education levels mirror those of its natives and may depress wage for a majority of them. 4) Within the EU, Great Britain is the most similar to the immigration economies in terms of its ability to attract skilled migrants and in the composition of immigrants across schooling groups.
\end{abstract}

Key Words: Determinants of International Migrations, Impact of Migrations, Skills, Migration Policies, European Union.

JEL Classification Codes: F22, J31.

\footnotetext{
${ }^{1}$ Giovanni Peri, Department of Economics, University of California, Davis, One Shields Avenue, Davis, CA 95616. gperi@ucdavis.edu.

I thank Barry Eichengreen for inviting and stimulating this contribution. Peter Lindert provided very helpful and insightful comments and discussion. I also thank Anna Maria Mayda and participants to the Berkeley-Vienna Conference, 2005 for helpful comments. Ahmed Rahman provided outstanding assistance with the editing of the paper. Errors are mine.
} 


\section{Introduction}

During the nineties the world experienced an increase in the flows of goods, capital and people across countries, helping to make "globalization" a common buzzword in the media and political discourse. While economists generally consider this trend beneficial to all economies, a heated debate concerning the "discontented" or the "losers” of globalization has held center-stage in the theatres of politics, economics and the media. ${ }^{2}$ The increased trade in manufacturing products and the outsourcing of traditionally skilled services to developing countries has compelled some trade economists to think more carefully over some of the particulars in extant trade theories. ${ }^{3}$ Certainly no aspect of globalization is regarded with more anxiety (or bound to produce more pronounced changes to our societies) than the large migratory flows of workers who seize economic opportunities by moving across countries. The United States, always a powerful attractor of migrants, has recently regained the position it held at the beginning of the twentieth century as the quintessential immigration country. Similarly Canada and Australia have experienced very large and growing inflows of immigrants in recent decades. On the other hand, the European Union, ${ }^{4}$ a frequent point of departure for immigrants in the past (headed mainly to North America, and Australia) is now becoming the destination of choice for a growing number of Turks, North Africans and Eastern Europeans.

This motley collection of internationally mobile workers, with varying skills, educational attainments and abilities, represents an extraordinary potential resource for both the US and the EU. From a political and economic point of view, however, native citizens more often than not perceive immigration as a threat. Immigrants are often seen as the harbingers of job loss and wage reductions for home-born-workers, or the unwitting disseminators of traditions and values that may "corrupt" the authenticity of native institutions. In some extreme cases, they are seen as a threat to national security. As social scientists, therefore, we are hard pressed to analyze more carefully the determinants and consequences of these migration flows in order to separate incorrect perceptions from

\footnotetext{
${ }^{2}$ See, for instance, Stiglitz (2002)

${ }^{3}$ See the debate between Samuelson (2004) and Bhagwati et al. (2004)

${ }^{4}$ Here and in the rest of the paper we refer to EU15 as "European Union". The eastern and central European countries (of recent accession to the EU) are excluded.
} 
reality. In the wake of the escalation of fear and intolerance for foreigners emerging in the EU, along with mounting uneasiness in foreign-born communities (e.g. in the urban peripheries of France) it is particularly important to focus on immigration and internal mobility in the European Union, looking into both its causes and consequences. One critical aspect of immigration (little inquired in the international literature due to the lack of systematic cross-country data) is the education and skills of migrants vis-à-vis those of natives. Attracting highly skilled engineers or scientists in a country likely depends on different factors, and has different consequences, than attracting low skilled manual workers. Some countries (such as Canada and Australia) have immigration systems that aim at selecting immigrants based on their skills (schooling, abilities). Others, like the US, keep only general quotas for immigrants and favor family reunifications, but also maintain special channels to allow highly trained professionals into the country (H1B visa program). The EU is currently debating over which system to adopt, and thus needs a clear understanding of the determinants and consequences of immigration on which to base such a decision.

Recent studies have made important progress in analyzing both the determinants of international migration ${ }^{5}$ and the effects ${ }^{6}$ of such migration on natives. While several issues are still debated, this article follows a rather standard and uncontroversial approach in analyzing the determinants of international migration by means of a gravity equation that includes geographic and economic determinants. We then build on previous work (mainly Borjas, 2003 and Ottaviano and Peri, 2005) in order to evaluate the impact of immigration on the wages of natives.

This paper uses data made available only recently (March 2005) on the stock of international migrants in OECD countries, as measured by censuses held in each country in the year 2000. Individuals over 15 years of age residing in each of 28 OECD countries are classified according to their country of birth and their schooling level, as recorded by the census of the country of residence. This allows a cross-sectional picture of the stock of

\footnotetext{
${ }^{5}$ See for instance Hatton and Williamson (2002, 2004), Clark, Hatton and Williamson (2004), Mayda (2005). For a more descriptive overview see Massey et al (1993) and Zlotnik (1998).

${ }^{6}$ There is a long tradition of analyzing the impact of immigrants on US wages. Early influential papers are Altonji and Card (1991), Borjas (1987), Card (1990), Grossman (1982). More recent important articles are Borjas et al. (1997), Borjas (1999, 2003), and Card (2001). Baker and Benjamin (1994) analyzed the impact of immigrants in Canada. For the impact of immigrants in Europe see Angrist and Kugler (2003).
} 
foreign-born workers in each country by education group. We use this data together with country-level data on education, population and wages to establish some facts and to highlight some interesting correlations, with particular attention to the European Union (EU15) in comparison with the main immigration economies (the US, Canada, Australia and Switzerland). Studying the mobility of highly educated individuals (i.e. people with tertiary education) serves as a central focus of this paper and reveals interesting and important facts. This exploratory study highlights certain regularities which we hope to analyze with further research. In particular we find that four general features clearly characterize the current state of the EU vis-à-vis the US and other important immigration economies:

1) The European Union exhibits surprisingly low levels of long-run cross-country mobility of its labor force. While migration flows between EU countries are well known to be lower than migration flows between US states, we are surprised to find that this gap remains even after controlling for economic and geographic determinants. This is true even for the most educated workers. Far from being an integrated labor market like the US, the union of European countries seems to have no particular effect in facilitating the long-run mobility of residents across its countries.

2) The European Union lags far behind the US and other immigration countries (Canada, Australia, Switzerland) in its ability to attract immigrants, including highly educated ones. While part of the difference in attracting highly educated workers can be explained by the lower returns to education in continental Europe relative to the US, a large and significant difference persists even after controlling for this.

3) Interestingly, we find that the educational distributions of foreign-born in immigration countries like the US, Canada and Australia and Switzerland are "complementary" to the distribution of skills of native born. More specifically, the educational group comprising the largest share in the native population has the relatively smallest share among foreign-born individuals. This fact, emerging from our calculations on the wage-effects of immigrants, implies that these countries receive an influx of immigrants with skills that are relatively scarce in the home country, hence driving up home wages. In contrast, the EU attracts immigrants in largest proportion among the groups of less educated workers (with primary education degrees) which constitute the 
largest educational groups for its natives as well. The educational distribution of immigrants to the EU therefore replicates (rather than complements) the education of its native population and hence may be more harmful to their wages.

4) Finally, looking in greater detail at the most important economies within the EU15, Great Britain appears to be most similar to the immigration economies (USA, Canada, Australia) in terms of its ability to attract skilled immigrants and in the schooling distribution of these immigrants. Its features should perhaps serve as helpful guidelines for other EU countries. On the other hand, Germany and France appear to attract mainly unskilled workers, and share an apparent inability to consistently attract highly educated migrants.

These four features characterizing the migration behavior of workers with different levels of education, particularly 2 to 4 , are certainly the outcomes of differences not only in immigration policies but also in labor markets, higher education policies and economic performances. The labor market and education opportunities that are available often serve as the main pull factors that attract educated immigrants, while immigration policies themselves simply act as a device to regulate their flows. Attracting immigrants from the pool of highly educated people will probably require the EU to reform its labor and goods markets to facilitate higher competition and to redefine its tertiary education strategies, on top of reforming its immigration laws.

The rest of the paper is organized as follows. Section 2 describes the data and presents some statistics on international migration flows across OECD countries and their composition by education. We devote particular attention to describing the EU as a whole and its main economies as the countries of destination for international migrants. Section 3 analyzes the determinants of bilateral migrations using a gravity model, and section 4 focuses on migratory flows of highly educated workers. Section 5 describes the skill composition of natives and immigrants in both the EU and main immigration countries, and section 6 calculates the impact of immigration on the wages of natives. Some interesting indications on the political economy of immigration emerge from this section. Section 7 concludes the paper. 


\section{Description of the Data and Summary Statistics on Migration}

Several sources collect data on yearly migratory flows across countries (e.g. the International Migration Statistics for OECD countries and the Continuous Reporting System on Migration, SOPEMI). However there is very little information on the level of schooling or on any other measure of the skills of these migrants. In order to have accurate information on these variables one has to rely on population censuses held by each country to record the stock of foreign-born and their schooling. Recently, the OECD has gathered comparable data on the presence of foreign-born grouped by levels of education and country of birth from censuses of all the developed countries (OECD, 2005). There are three education groups that can be consistently tracked across countries: people with primary education (some education or the full primary degree), people with secondary education (some education or the full secondary degree) and people with tertiary education. We will sometimes refer to these three groups as "low," “intermediate" and "high" levels of education, respectively. These educational categories are consistent with those of the Barro and Lee (2000) data set on education across countries based on the International Standard Classification of Education (ISCED). ${ }^{7}$ These data allow us to construct the stock of migrants for a matrix of all OECD countries (country of origin by country of destination). These stocks measure the long-run outcomes of migratory processes and are less subject to the yearly fluctuations of migratory flows. They constitute a measure of long-run migratory behavior across countries and skills. The data on country population, GDP and area are from the Penn World Tables release 7.0. The data on wages for each schooling group are calculated using average wages (from average GDP per capita) and the estimated returns to schooling specific to each country, reported by Bils and Klenow (2001). Finally all the bilateral geographical data (distance, border dummies and language dummies) are taken from Glick and Rose (2002).

\subsection{The EU Relative to Other OECD Economies}

Let us first consider the overall size of the stocks of immigrants and emigrants for the countries of the European Union, together with the same stocks for the other OECD

\footnotetext{
${ }^{7}$ See section 2.2 below for details.
} 
economies. Table 1 reports some shares that provide an idea of the ability of each OECD economy to attract foreign-born as well as the propensity of its natives to migrate abroad. Column 2 reports the share of foreign born in the resident population, while column 3 reports people who were born in the country and reside abroad as a share of the total born in the country. These values thus provide information on the stocks of immigrants (column 2) and emigrants (column 3) for each OECD country in year 2000. Column 1 reports the difference between immigrants and emigrants (with a positive sign indicating net immigration and a negative sign indicating net emigration) as share of the total population born in the country. While most of the current issues in the European Union and the US concern the presence of foreign-born immigrants as a share of total residents (column 2) it is also interesting to analyze the magnitude of the stock of emigrants and the balance of the two. Let us note a few interesting facts that emerge from the data. In Table 1 countries are ranked in decreasing order of the percentages reported in column one, i.e. from the largest net "attractors" of immigrants to the largest net "suppliers" of emigrants (as percentage of their population). Excluding the extremely small country of Luxembourg we call "immigration" countries the four countries at the top of the list (all outside the EU). They are, in decreasing order, Australia, Switzerland, Canada and the United States. These countries exhibit extremely high net immigration rates, equal, respectively, to $27 \%$, 23\%, $19 \%$ and $13.5 \%$ of their native populations.

While Australia and the US are purely countries of immigration (as their stock of emigrants is less than $2 \%$ of their native-born populations), around $5 \%$ of the native populations of Switzerland and Canada have emigrated abroad (mainly to the EU and the US, respectively). They attract, however, a far larger number of immigrants, resulting in large net migrations. Compared to these economies the EU15, ${ }^{8}$ considered as a whole, maintains a substantially smaller share of foreign-born residents (i.e. those born outside the EU). This percentage is equal to 7.2. On the other hand 3.5\% of EU natives reside outside the EU, so the net immigration rate is a scant $4.7 \%$, less that a third of the US's rate and less than a fifth of Australian's rate.

\footnotetext{
${ }^{8}$ EU 15 includes the following countries: Austria, Belgium, Denmark, Spain, Finland, France, Germany, Greece, Italy, Ireland, Luxembourg, The Netherlands, Norway, Sweden, The United Kingdom.. Italy is never included, however, in our statistics, due to lack of data.
} 
Looking at countries within the EU, some such as Sweden, Austria and Belgium can be characterized as relatively "open” economies from a migratory point of view, with large percentages of both immigrants and emigrants. Others such as France and Germany are mainly immigration economies, while a few such as Ireland and Portugal remain net emigration economies. The percentages in Table 1 however do not distinguish between whether immigrants and emigrants are going from/to other countries within the EU or outside of it. As our focus is on the EU as a whole, we make the distinction between mobility inside and outside of the EU in Figure 1. Before moving to that, however, let us note two other typologies among the migratory patterns of OECD economies. First, some of the major countries of emigration into the EU and the US, such as Turkey, Poland, Hungary and Mexico are within the group of OECD countries analyzed in this study. Mexico in particular is a pure emigration economy, with 9\% of its native people living abroad, mostly in the US. Second, some OECD countries essentially close off labor flows altogether. Most notably, Japan has a stock of immigrants and emigrants smaller than $1 \%$ of its population. While we hardly think that this is applicable to the EU, the case of Japan shows that it is possible to run a developed economy geographically close to less developed ones and resist immigration pressures almost entirely.

Figure 1 shows the foreign-born population as a percentage of the total residents in each of the EU15 countries (with the exception of Italy, due to lack of data). The countries are arrayed from left to right in decreasing order of total percentage of foreign-born. The share of the bar that is colored in red represents immigrants from other EU countries, the portion colored in blue measures the share of immigrants born outside the EU. Aside from the very small and highly "international" country of Luxembourg, Germany and Austria exhibit the largest ability to attract “extra-communitarian” immigrants (interestingly Greece is the next highest for share of foreign-born, mostly coming from Turkey and Cyprus). The Netherlands, France and the UK also attract non-trivial percentages of extracommunitarians.

Very surprisingly, for all countries except Ireland and Luxembourg, the share of immigrants from outside the EU is larger than the share from inside the EU. Considering the complete elimination of political barriers to the movement of labor since 1992, the strong cultural and linguistic commonalities within the EU, and the geographic proximity of these 
countries, one marvels at the trivial degree of mobility of EU citizens. On average only 2.2\% of the residents of an EU country are born in a different EU country. Section 3 below will inquire more formally about the low cross-country mobility of Europeans. Here it is enough to mention that taking the US as a model of an integrated labor market, and considering cross-state mobility as a measure of internal mobility, the percentage of US residents born in one state and living (working) in a different state was, on average in year 2000, around 30\%. This is fifteen times larger than the cross-country analog for Europeans.

In short, while the EU15 is still far from attracting the percentages of extracommunitarian immigrants comparable to those found in Australia, Canada and the US, some of its countries maintain shares of extra-communitarians close to $10 \%$ of their populations. Overall though, the long-run mobility of EU citizens across EU countries is extremely low.

\subsection{Education of Immigrants}

This article focuses its analysis on the skill composition of immigrants. Our goal is to characterize the different determinants and consequences of the international mobility of people with different levels of human capital (education). Human capital is a fundamental determinant of productivity (Hall and Jones, 1999), innovation and growth (Jones 2002) across countries. Moreover workers with different educational attainments embody different amounts of human capital and are imperfect substitutes in production (Katz and Murphy 1992, Ciccone and Peri, 2005). Therefore it is important to analyze the international migration of workers with a particular focus on their educational levels. Considering the EU15 as one economy, Table 2 (divided into 3 parts, 2A, 2B and 2C) reports the net immigration rate (immigrants minus emigrants) as a percentage of the total resident population for each of the three schooling groups, for both the four main immigration countries and the EU15. Table 2A column 1 shows the immigration rates of individuals with tertiary education for each economy. The absolute number of net immigrants with tertiary education is reported in column 2 and the total number of residents with tertiary education in column 3. Table 2B and 2C do the same for individuals with secondary and primary education. The classification of the education levels into the three groups follows the International Standard Classification of Education (ISCED). In particular the group of 
"primary school educated" includes the categories ISCED 0, 1 and 2. The group of secondary school educated includes ISCED 3 and 4 and the group of tertiary educated includes ISCED 5 and 6. Each table ranks the four immigration countries and the EU in decreasing order of immigration rate for each group. A very important fact is established in table 3A, substantiating the fears of Europeans that many of their best brains are leaving the EU to the US and other advanced economies. While Australia, Canada, Switzerland and the US attract a very large number of highly educated foreigners (these include professionals, engineers, scientists, and managers with crucial roles in promoting the productivity and growth of the host country) the EU15 experiences a net loss of highly educated individuals.

Between 15 and $36 \%$ of the population with tertiary education in the US, Canada, Australia and Switzerland are foreign-born. In contrast the EU cannot even attract enough foreign-born to make up for its brain drain. While the net drain is small, the gross numbers reveal that 2.5 million college-educated Europeans live abroad and only 2.44 million foreign college-educated workers operate in Europe. This is perhaps the most alarming figure of the whole article. ${ }^{9}$

In relative terms the ability of Australia to attract highly educated foreign born is the most extraordinary: a third of the resident population with tertiary education is foreign-born. In terms of sheer quantities the United States attracts the largest share of internationally mobile highly educated workers with an impressive 7.5 million tertiary-educated foreignborn. This is like adding to the US the highly educated population of a country as large as Canada. Talents from all over the world are attracted in very large numbers to jobs located in the US.

The ability to attract immigrants into the EU exceeds its stock of emigrants exclusively in the category of less educated workers, where the net stock of immigrants is $3 \%$ of the resident population. Notice also that relative to Australia and Canada (countries that disproportionately attract highly educated workers), Switzerland and the US disproportionately attract the group of less educated workers. An impressive $30 \%$ of less educated workers in the US were foreign-born in the year 2000. Notice, however, that both in relative and absolute terms the number of natives with only primary education is much smaller in the US than in the EU. While the group of US-born residents with a college degree

\footnotetext{
${ }^{9}$ See also the Report EEAG (2003) on the drain of talents from Europe.
} 
(see column 3 of table 2A) is $40 \%$ larger than the corresponding group for the EU15, US natives with primary education are less than half of EU15 natives with primary education. We can then say that the US economy is progressively substituting natives with foreign-born in the low education groups. We will come back on this point later.

All in all, the EU exhibits a much lower capability of attracting immigrants within any skill group, and perhaps most alarmingly, this inability is particularly apparent for the group of the most highly educated workers.

\section{Determinants of Emigration and the EU Effect}

The simple statistics presented above are suggestive of two important characteristics of migration in the EU: a low degree of internal mobility and a low ability, relative to other immigration countries, to attract foreign immigrants, including the highly educated. We need a more structured econometric analysis, however, in order to better understand the causes of these two phenomena. The low internal mobility, for instance, may be due to the equalization of wages across EU countries, which would weaken incentives to migrate. Alternatively, genuine barriers to mobility may exist. Similarly, the inability to attract highly skilled foreigners may be a consequence of low wage compensation, or of unattractive post-tertiary education systems, or of hostile immigration policies and other institutional features that penalize immigrants in this group. To shed light on some of these issues we use the data on the bilateral stocks of emigrants across all OECD countries (by origin and destination) and perform an econometric analysis using a gravity equation that includes the economic and geographic characteristics of countries (of origin and destination) in order to explain these flows. Moreover we differentiate migrants across the three education groups to determine whether they respond differently to economic and geographic incentives and, in general, whether some groups are more mobile than others.

\subsection{A Gravity Approach}

The basic gravity regression, used to analyze gross trade flows between countries, assumes that (the natural logarithm of) those flows depend on the size of each of the two 
trading countries (measured as their GDPs) and on factors that can influence bilateral trade costs (distance, contiguity, trade agreements, common culture, access to the sea and so on). ${ }^{10}$

The gravity equation has also been used in the international migration literature. An early work by Helliwell (1998) uses it to analyze migration between US states and Canadian provinces, and more recently Karemera et al. (2000) use this framework to analyze immigration in North America, while Mayda (2005) adapts it to a panel of international migration flows. In its most basic form the gravity equation for migratory flows explains the total emigration from a country of origin to a country of destination using the economic characteristics of the two countries (population and GDP per person) along with bilateral geographic characteristics (distance, common border, access to sea, common language and trade agreements). Occasionally, if the data allow it, more characteristics of both the country of origin and the country of destination are included in order to account for immigration policies and other relevant characteristics. Our empirical strategy follows the general guidelines described above with a novel feature. We include as dependent variables different education groups separately and correspondingly, we enter as explanatory variables the economic characteristics relative to each education group (their wage, their population) in the country of origin and of destination. We run some specifications pooling the education groups together and others separating the three groups.

\subsection{Geographic Determinants}

In order to carefully analyze the effects of bilateral characteristics (such as distance, sharing a border or speaking a common language) on the emigration flows of each skill group, we first run a generalized gravity equation in which we control for all possible characteristics (economic and non-economic) of the countries of origin and destination by including origin and destination dummies. The data set includes $756^{11}$ observations on gross emigration rates between 28 OECD countries for each of three schooling groups. We use these observations to estimate the effects of geographic (and other bilateral) variables after controlling for 28 country of origin effects and 28 country of destination effects. The basic regression, whose estimated coefficients are reported in Table 3, is as follows:

\footnotetext{
${ }^{10}$ See Feenstra (2003) for a survey of the gravity approach in the trade literature.

11 The native of each one of the 28 countries can migrate to any of the other 27 . Hence the number of observations for the gross flows is $756=28 \mathrm{X} 27$.
} 


$$
\ln \left(E_{k, i, j}\right)=\alpha_{i}+\beta_{j}+\gamma_{k}+b_{1} \ln \left(\text { dist }_{i, j}\right)+b_{2}\left(\text { bord }_{i, j}\right)+b_{3}\left(\operatorname{lang}_{i, j}\right)+b_{4}\left(\operatorname{tradeag}_{i, j}\right)+\varepsilon_{i, j}
$$

$E_{k, i, j}$ is the total number of emigrants in education group $k$, born in country i (called the country of origin) and residing in country $\mathrm{j}$ (called the country of destination). $\alpha_{\mathrm{i}}$ is a set of 28 country of origin fixed effects, while $\beta_{\mathrm{j}}$ are 28 country of destination fixed effects. $\gamma_{i}$ are education-specific effects and capture the higher or lower propensity of a skill group to migrate. The other variables are relative to each couple ( $\mathrm{i}$ and $\mathrm{j}$ ). They capture, respectively, the distance between the two countries (dist $\left.t_{i, j}\right)$ and the presence of a common border $\left(\operatorname{bord}_{i j}\right)$, a common language $\left(\operatorname{lang}_{i, j}\right)$ ) or a trade agreement between the countries $\left(\right.$ tradeag $\left._{i, j}\right)$. Each of these variables affects the costs of migration and therefore may affect migratory flows. $\varepsilon_{\mathrm{ijk}}$ is a zero-mean random error. As there may exist correlation in the shocks to gross migration for different skills between a particular pair of countries, we cluster the standard errors by country-pair. Specification I of Table 3 reports the estimated coefficients of regression (1) while the other three specifications (II, III and IV) report the coefficients for the same regression run separately for each skill group, i.e. allowing for different effects of each explanatory variable on the emigration flows of each group. Finally in each regression we include a dummy (labeled “within EU”) that takes a value of one if the two countries (origin and destination) are both within the EU15 and zero otherwise. A positive and significant value of this variable implies that migration within EU countries is more intense than between two average OECD countries, once we control for the bilateral characteristics that affect migration.

Specification I of Table 3 shows that all the bilateral variables have the expected signs and enter significantly in the regression. As the dependent variable is measured in natural logs (we add one to the very few cells with 0 emigrants) the coefficients are elasticities. Reducing distance by half (50\%) increases emigration flows by 65\%. Sharing a border increases overall migration between two countries by $74 \%$, while speaking a common language increases migration by $45 \%$, and belonging to the same trade agreement increases it by $20 \%$. Moreover, for a given set of bilateral characteristics, the group of individuals with intermediate or high education exhibits a tendency to migrate $43 \%$ more than the group with low education (the omitted dummy). Finally, confirming the statistics on low 
mobility within the EU, the regression shows no significant effect of belonging to the EU on cross-country migration. This is surprising as there are usually very restrictive immigration policies across countries, while there are no formal restrictions on labor mobility across EU countries.

Considering the mobility of each education group (column II to IV), a few interesting indications emerge. First, highly educated workers appear to be less sensitive to distances and common borders in shaping their emigration behavior. Highly educated people are likely to be better informed and better equipped to seize good job opportunities in distant countries. However the linguistic commonality plays a bigger role for highly educated, whose jobs no doubt involve professional skills in which the mastering of a language is crucial. On the other hand the importance of a common border for migration of low educated people is substantial. The existence of informal networks and word-of-mouth information, particularly strong in the presence of geographic contiguity, may be the main channel to foster the migration of less educated workers. The effect of sharing a border, in fact, is large and statistically significant only for the group of less educated individuals. Finally the "within EU" effect is not significant for any skill group. Its point estimate is positive for the highly educated and negative for the other two groups, but highly insignificant for all. The EU has thus far not promoted cross-country integration of labor markets at any level of skill.

\subsection{Economic Determinants}

Specification (1) absorbs all the idiosyncratic characteristics of the countries of origin and destination into dummies. This is convenient because it solves the problem of country-specific omitted variables; however it does not provide any understanding of what economic characteristics of the country of origin and destination affect the magnitude of emigration flows. In this section we more closely follow the traditional gravity specification by including, as potential determinants of emigration, the sizes of the country of origin and destination (measured by the population born in each of the two) and the average wage of the education group in both countries. Since we maintain 
the three education groups as the primary unit of analysis, we need to identify both the size and the wage of each group within each country (origin and destination). Specifically we run the following regression:

$$
\begin{aligned}
& \ln \left(E_{k, i, j}\right)=\alpha_{1} \ln \left(\text { pop }_{k, i}\right)+\alpha_{2} \ln \left(\text { pop }_{k, j}\right)+\beta_{1} \ln \left(w_{k, i}\right)+\beta_{2} \ln \left(w_{k, j}\right)+ \\
& b_{1} \ln \left(\text { dist }_{i, j}\right)+b_{2}\left(\text { bord }_{i, j}\right)+b_{3}\left(\operatorname{lang}_{i, j}\right)+b_{4}\left(\text { tradeag }_{i, j}\right)+\varepsilon_{i, j}
\end{aligned}
$$

The variable $\operatorname{pop}_{k, i}$ measures the total population with schooling level $k$ born in country $i$, and $w_{k . i}$ is the average wage of workers in education group $\mathrm{k}$ in country $\mathrm{i}$. In order to measure these variables we need additional data and assumptions. We calculate the population size of each skill group using population data from the Penn-World Tables (release 7.0) and the share of population in each schooling group using the Barro and Lee (2000) data set, which is currently updated to the year 1999. The wage for each skill group is harder to find for a large set of countries. As such we calculate them as follows. We assume that the average wage in a country is proportional to the average GDP per capita and is earned by workers with the average schooling level of the country. Then we construct the wage for each education group in each country using the estimated returns to schooling specific to the country, taken from Bils and Klenow (2001) and we use the median years of schooling for each skill group (taken from the Barro and Lee, 2000 dataset and relative to year 1999). This step implies a large loss of countries as only 18 of the 28 OECD countries have estimates for their returns to schooling. The implicit assumption is that a person with a certain level of schooling in a country looks at the wages of people with similar schooling in other countries when deciding whether and where to migrate. Therefore a country that pays high wages to less educated workers should attract more workers in that group. In spite of certain limitations, this procedure is more accurate than simply proxying the earnings of all skill groups with the average GDP per capita in the countries of origin and destination. Such a procedure would completely miss the effects of the wage distribution on the skill distribution of immigrants.

Table 4 shows the estimated coefficients for regression (2), pooling all groups in column I, and separating them by group in specifications II to IV. The effects of the 
geographic variables are similar to what was estimated in Table 3, only the effects are smaller for distance and larger for sharing a common language than previously estimated. The sizes of the groups of origin and destination, $\ln (p o p)$, are very significant in determining the size of emigrants, although their coefficients are smaller than one. This implies that larger groups or countries tend to receive a larger number of emigrants, but in numbers less than proportional to their original populations, so that the share of emigrants and immigrants tend to be smaller for larger countries. Consistent with previous results (e.g. Mayda 2005) wages in the country of destination are a very important determinant of migration, with a positive elasticity close to 3 (which suggests that a wage increase of $1 \%$ in the country of destination increases the stock of immigrants by 3\%) while the wage in the country of origin has a smaller and insignificant effect. Often the theory predicts an ambiguous effect of this wage on emigration. On one hand people with very low wages (those in poverty) often do not have the means to emigrate, so that an increase in wages may lift these people out of poverty and hence raise the emigration rate; on the other hand as the wage continues to rise and economic opportunities improve the incentives to emigrate diminish. As a result of these two offsetting influences people often find a small or zero effect (or sometimes a non-linear effect) of wage changes in the country of origin on emigration flows. We also confirm the higher mobility of intermediate and highly educated workers. Moreover, this specification strengthens our previous finding that belonging to the EU actually has a negative effect on emigration flows. When we control only for differences in wages and population, living within the EU is associated with a much lower tendency to move between countries. Two hypothetical non-EU OECD countries would have more than twice the bilateral migration flows as two EU countries with identical wage, population and bilateral geographic characteristics! Part of the countryspecific lack of mobility not due to wage differences, previously captured by country dummies in Table 3, is now absorbed by the EU effect.

Specifications II to IV in Table 4 confirm the stronger effects of common languages on the migration of highly skilled individuals and, interestingly, the higher sensitivity to wages in the destination country for the less educated group. Confirming the non-monotonic effect of wages in the country of origin on labor flows, the 
emigration of highly educated individuals (who are certainly not poor even in poorer countries) respond negatively, though not significantly, to an increase in that wage. Less educated people, on the contrary, respond to higher wages in the country of origin with a higher, though not significant, emigration rate. The effect of the EU dummy in each regression confirms the lack of mobility particular to within-EU countries, but also shows a smaller negative effect on the group of highly educated relative to less educated.

In general the regressions show that highly educated workers are on average more mobile, less affected by distance and proximity and more affected by common languages in their migratory choices than are the less educated. Moreover migration flows for all skill groups respond very strongly to the wages in the country of destination and less strongly or clearly to the wages in the country of origin. Finally the EU seems to have an unusually low level of cross-country mobility even relative to the other OECD countries, once we control for the well-known geographic and economic determinants of emigration.

\section{Ability to Attract Educated International Migrants}

Let us now concentrate our analysis on the international mobility of highly educated people. In light of the above results we can begin to analyze the reasons for the relative inability of the EU to attract highly educated foreign born workers. First of all there is a tendency of large economies to attract foreign educated workers in smaller proportions than domestic workers. The percentage of foreign-born from these groups is consequently typically lower in larger economies. However the US, an economy of comparable size to the $\mathrm{EU}$, has a $14 \%$ share of highly educated residents who are foreign-born relative to $5.9 \%$ in the EU: clearly none of this difference is driven by the size of the economy. Second, the lower returns to education in many European countries compared to the US (though not to Canada and Australia, which have similar returns) and the sensitivity of migration of highly skilled workers to the wages in the country of destination also explains some of the differences. In particular, looking at differences in the returns to schooling between 
Germany $^{12}$ (7.7\% per year of schooling) and the US (9.3\% per year of schooling) and differences in average incomes and years of schooling, one observes that the salaries for the highly educated are 30\% higher in the US than in Germany (in terms of purchasing power). Given our estimated sensitivity of emigration to wages (for highly educated workers), this translates into a 50\% larger inflow of highly educated to the US, all else equal. Yet this difference is still too small to explain the actual percentage differences in migration between the highly educated foreign-born in the EU and the US. Using German high-skill wages as the representative skilled wage series for continental Europe, bringing these to the US levels would still only increase the share of foreign born to about 9\% (5.9\% $+0.5 * 5.9 \%$ ). Five percentage points of difference, equivalent to nearly $100 \%$ of the size of total immigration of highly skilled workers in the EU, remain unexplained.

To be more precise in the quantification of the unexplained inability to attract educated foreign workers, we run specification (2) again, but add selected country of destination dummies. In particular we add an "EU" effect (equal to one when the destination is a EU country) and a "US" effect (equal to one when the destination is the US). Then we add dummies for specifically selected immigration countries. Finally we compare Germany and the UK as destination countries. The estimates of the coefficients on these dummies are reported in Table 5. Each column reports coefficients from one regression identical to specification II in Table 4 (hence restricted to highly educated workers) with the inclusion of these dummies.

The sign and magnitude of these estimates can be interpreted as the unexplained excess ability or inability of the destination country to attract skilled immigrants, once we control for the geographic and wage determinants of migration. Specification I includes only EU and US dummies as destination countries, while specification II adds specific effect for Canada and Australia. Specification III includes 18 dummies to control for all observed and unobserved characteristics of the countries of origin. Finally specification IV considers a specific effect for Germany and the UK as destination countries (these are the only two large EU countries included in the regression, as Italy lacks data on migration and France lacks data on the returns to schooling).

\footnotetext{
${ }^{12}$ Here and in the rest of the paper we take German's returns to schooling as representative for the EU.
} 
In each specification the EU effect is negative and significant relative to the average effect for OECD countries (standardized to zero). In contrast the US effect is positive, significant and stands as the largest effect even when we include other immigration economies. Considering that the average share of highly educated foreignborn in an OECD country is $2 \%$, the negative effect estimated in column 3 implies that the EU (even with wages and population identical to the US) would host a percentage of foreign-born equal only to $0.84 \%$ of its residents, while the US would receive $11.7 \%$ of all its highly educated from abroad. This difference (likely due to a combination of policies, institutions, higher education opportunities, non-monetary incentives, and other factors) accounts for $80 \%$ of the share of highly educated immigrants in the US, and over-accounts for the disadvantage of the EU. Somewhat unsatisfactorily, the largest part of the difference between the US and the EU in attracting skilled foreigners is captured by these unexplained dummies. Certainly more careful analysis of the immigration policies and institutional characteristics of the countries may reveal important determinants currently buried in the fixed country effect. Finally, specification IV shows that when we allow differences across EU countries, the UK emerges among the large EU economies as the country that, for given wages and geographic characteristics, has the largest unexplained capacity to attract highly educated foreign-born. While the specific effect of Germany as a destination country is equal to the OECD average (the coefficient on the dummy is not different from 0 ) the UK has a capacity almost four times as large as the average to attract educated immigrants (+280\%). This is still far from the US and other immigration countries, but remarkable for EU standards.

While Table 5 confines the analysis to the group of highly educated immigrants, similar regressions run for the groups of intermediate and less educated (not reported) produce similar results. We therefore wish to emphasize the low ability of the EU to attract workers in general at any level of human capital and skill. This tendency, already shown by the simple statistics on immigration of Section 2, is dramatically confirmed by the econometric analysis. Particularly when compared to the US, the countries of the EU15 (with the possible exception of the UK) have a remarkably weak ability to attract workers. 


\section{Skill Composition of Native Workers and Skill Composition of Immigrants}

Essential to any immigration policy is the stipulation of not only the total number of immigrants allowed in the country, but also the criteria for admitting them. For such decisions it is crucial to consider the skills, education and ability of immigrants, especially in assessing the effects of immigration on the wages and income of natives. Workers with different schooling levels are effectively different factors of production, since they perform different tasks and choose different occupations. Thus they are not perfectly substitutable. Hence by shifting the relative supply of different skills, the inflow of immigrants affects the relative scarcity (and wages) of different groups. Some groups of natives gain while others lose as a result of these inflows. Furthermore, if we believe that foreign born workers are not perfect substitutes for natives even within the same education group (because of different abilities, occupational choice and working preferences - see Ottaviano and Peri, 2005 for a fuller discussion) the gains for local workers from immigration would be differentiated even further. In particular, for a group of native workers with a certain educational attainment, most beneficial to them would be the inflow of workers with vastly different levels of education. These immigrants would complement their abilities and increase their productivity, while the inflow of workers with similar education and skills would compete for similar jobs, possibly pushing wages down and (at least temporarily) unemployment up.

Since all the immigration economies considered here are democratic, ultimately the selection of migrants is determined via immigration laws that are approved and supported by the citizens (natives). We should then expect that the combination of immigrants allowed in the country is one that benefits the majority of its citizens, particularly the median voters. Hence in a political-economy equilibrium where the median voter chooses the immigration policy, the largest skill group in the country should limit the inflow of foreigners with the same level of education and encourage the inflows of those with different levels of education. ${ }^{13}$ In particular, if one group has an absolute majority of people in the country, it should succeed in keeping the share of foreign born in that skill group among the smallest of all immigrant groups, in order to minimize competition from foreigners and maximize the benefits from complementarities. Table 6 shows the composition of the native population

\footnotetext{
${ }^{13}$ See Ortega (2004) for a formalization of this idea.
} 
across education groups (upper panel, 6A) and the presence of foreign-born in each skill group as the percentage of the total residents in that group (lower panel, 6B). The first four rows report figures relative to the immigration countries, the fifth row reports those for the EU15 and the last three rows show the figures for the three largest EU economies (France, Germany and the UK).

Consistent with the political economy of immigration laws, each of the immigration countries (Australia, Canada, Switzerland and the US) follows the principle described above: the largest skill group in each country (in most cases an absolute majority, and marked in bold in the upper table) corresponds to the group with the lowest percentage of foreign-born (marked in bold in the lower table). To eyeball this pattern we report in Figure 2 the distribution of the native population across the three education groups (solid line) and the share of foreign-born in each group (dotted line) for each of the immigration countries and for the EU. For each immigration country, represented in the top four panels (the US, Australia, Canada and Switzerland), it is easy to perceive the "mirror image" behavior of the two variables: the foreign-born are relatively abundant in the groups where natives are less concentrated in absolute terms. For the EU on the hand (bottom graph in the panel) the two variables "move together": the foreign-born are relatively abundant in those education groups (the less educated) already prominent within the native population.

This feature of these immigration countries is very interesting because the educational compositions of their populations are remarkably different. Australia has a relative majority of less educated individuals and Canada has a rather balanced population (with a small majority of people with secondary schooling), while Switzerland and the US have relatively large intermediate groups, with an absolute majority of individuals with secondary school education. Correspondingly, the foreign born in Australia are over-represented in the group of medium and highly educated people (27\% of each group is foreign) and under-represented in the group of less educated (20\%). Canada has a more balanced distribution of immigrantskills, with a small over-representation in the low and high schooling groups and underrepresentation in the medium schooling group. The US and Switzerland have a disproportionately large share of immigrants with high and low skills and a disproportionately small share in the intermediate group, thus complementing the distribution of natives. In general the presence of a large group of natives with a certain schooling level is 
associated with a relatively small share of foreign-born in that group for all the large immigration economies.

This is however not true for the EU. While the absolute majority (53\%) and the median voters in the EU belong to the low-education group, this group is also the one with the largest share of foreigners. Possibly because European workers have other means of protecting their wages from market competition (unionization, insider's advantages) immigration policies have not been targeted to shelter these low education workers from competition, even though they constitute the majority of the labor force in the EU area. One explanation for this is that there is no common immigration policy in the EU; as such we should look at individual countries. At the country level, however, the discordance between immigrant skill-levels in reality and those predicted by the political economy equilibrium remains in some countries. Interestingly, while the skill compositions of natives in France and the UK are similar to the EU average, with a majority of people with only primary education, the relatively uncompetitive French labor market attracts the largest share of foreigners among less skilled workers, while the more market oriented UK attracts more highly educated workers. Germany has a native skill composition concentrated among the intermediate levels of education and, in line with the political economy equilibrium, attracts more from the two extreme groups of skills. Ultimately, labor market distortions that have artificially protected workers in the EU may have reduced their concerns over the skill composition of immigrants, leading to sub-optimal immigration policies, at least from the point of view of the majority. This is confirmed by the fact that countries where these distortions are stronger (such as France) exhibit an immigrant skill-composition at odds with the one predicted by the political economy equilibrium, while those which are more market oriented (such the UK) show the largest presence of immigrants from education groups that benefit the country's majority, in line with the prediction of the political economy model. If immigration laws were established with an eye to the welfare of the native labor force, the EU would change the composition of its immigrant workforce, shifting it towards those with secondary and tertiary education who could most benefit the local economy. At the same time of course, better tertiary education and higher rewards to skills should complement any immigration policy if the EU is to compete for highly educated international migrants. 


\section{The Impact of Immigration on Wages}

The previous section emphasizes an intuitive idea: if the skill composition of immigrants is complementary to that of natives, then immigration benefits the majority of natives. This idea is based on the intuitive principle that, for a given factor, increasing the supply of a complementary factor of production benefits the factor, while increasing the supply of a substitute harms it. Here, we present a simple model of production that, using reasonable estimates of the elasticity of substitutions between education groups and between foreignborn and natives (taken from the literature), allows us to quantify the effects of the stock of immigrants on the wages of each native group and the average wage for all groups. We calculate these effects for both the immigration economies and the $\mathrm{EU}$ in order to illustrate again the contrast between the potentially large gains derived from migrants in the immigration countries vis-à-vis the very small gains or losses to the majority of EU individuals. These differences are due to the varying appropriateness of immigrant skill distributions and to varying abilities to attract highly educated workers.

\subsection{Production with imperfect substitutability of skills}

In order to compute the effect of a change in the supply of skills (due to migration) on the wages of natives, we need to assume an aggregate production function. We follow the recent labor (Katz and Murphy, 1992; Borjas, 2003) and growth (Caselli and Coleman, 2005) literatures and specifically Ottaviano and Peri, 2005. We assume that production of output, $\mathrm{Y}$, in country $\mathrm{i}$, takes place combining physical capital and the three types of labor inputs (classified by their schooling level) according to the following production function:

$$
Y_{i}=A_{i} K_{i}^{\alpha} \tilde{L}_{i}^{1-\alpha} \text { where } \tilde{L}_{i}=\left[\sum_{k=1}^{3}\left(\frac{L_{k, i}}{\tau_{k, i}}\right)^{\frac{\delta-1}{\delta}}\right]^{\frac{\delta}{\delta-1}}
$$

$A_{i}$ is country i's total factor productivity, $K_{i}$ is physical capital and $\tilde{L}$ is a CES labor composite of the three groups of workers with different education levels (Primary, Secondary and Tertiary). The terms $\left(1 / \tau_{\mathrm{k}, \mathrm{i}}\right)$ measure the efficiency of each group, while $\delta$ is the elasticity of substitution across these groups. Assuming the Cobb-Douglas 
combination of physical capital and the labor composite and considering the long-run accumulation of capital, any model with the above production function and optimal consumption converges to a balanced growth path with a constant real return to capital. Hence one can solve out K from (3) and calculate the wage (marginal productivity) of each type of worker as a function of total factor productivity, efficiencies $1 / \tau_{\mathrm{k}, \mathrm{i}}$ and supplies $\mathrm{L}_{\mathrm{k}, \mathrm{i}}$ of labor types. ${ }^{14}$ Once we have these formulas we can evaluate the impact of changes in the supply of foreign-born workers on the wages of each group of native workers to. It turns out that these elasticities depend only on the elasticity of substitution, $\delta$, which we take from the literature to be $1.5,{ }^{15}$ and on the wage and employment shares of workers in each group. We measure the first as shares in the population of each education group and the second using the wages imputed to each group in each country according to the procedure described in section 3.2. Then we evaluate the wage elasticity of natives in each group to a change in the supply equal to the total foreign-born population. In this section we assume that the total supply of each skill group is the sum of natives and foreign-born in that group: $\mathrm{L}_{\mathrm{k}, \mathrm{i}}=\mathrm{H}_{\mathrm{k}, \mathrm{i}}+\mathrm{F}_{\mathrm{k}, \mathrm{i}}$, where $\mathrm{H}_{\mathrm{k}, \mathrm{i}}$ is the total number of home-born residents in education group $\mathrm{k}$, while $\mathrm{F}_{\mathrm{k}, \mathrm{i}}$ is the total number of foreign-born residents in education group $\mathrm{k}$. We evaluate the percentage changes of wages for homeborn workers when $\mathrm{F}_{\mathrm{k}, \mathrm{i}}$ changes from 0 to the actual value for the year 2000 in each country.

Table 7A (the upper panel of table A) reports the results of this exercise for the four immigration countries and for the EU. Let us consider the effect of the stock of immigrants on Australian wages. Since Australia attracts mostly intermediate and highly educated workers, this influx increases the wage of less educated workers by 3.7\%, while it reduces the wages of the other two groups by 2.4 and 3.2 percentage points. This group of less educated individuals is the largest in Australia and nearly commands an absolute majority; hence the effect described above is beneficial to the largest skill group of the country. On the other hand Switzerland, which mostly attracts immigrants in the extreme education groups, experiences a wage increase for the intermediate (secondary) schooling group by 7 percentage points, while the other two groups experience wage losses of 11

\footnotetext{
${ }^{14}$ The details of the derivation and of the formulas are in Ottaviano and Peri (2005), pages 7 to 10.

${ }^{15}$ See, for instance, Katz and Murphy (1992), Caselli and Coleman (2005), Ciccone and Peri (2005).
} 
and 5 percentage points. Similar to this pattern (but less pronounced) are the effects of migration into the US and Canada. Notice that the aggregate effect on native wages (last column) is close to 0 in all cases. This results from our assumption of aggregate constant return to scale in production and of perfect substitutability of home and foreign-born in each education group.

Finally, consider the overall effects of immigration in the EU. The only group that benefits from immigration is the one with secondary education ( $+1 \%$ in their wages). But this group accounts only for $23 \%$ of the population, while the absolute majority of the population (with low levels of education) looses $0.4 \%$ of its wage. The competition from foreign-born at the low end of the education spectrum therefore harms Europe more than the US. One may argue that the solution is to promote educational policies rather than change immigration policies; in particular many have stressed that the EU must increase its graduation rates in tertiary education, hence increasing the average education of native Europeans. It seems possible, however, that any benefits from educational restructuring might be undermined by current EU immigration policies.

\subsection{Gains from complementarities}

I have argued in previous articles (Ottaviano and Peri, 2005) that the above procedure, which assumes perfect substitutability between home and foreign born workers within an education group, understates the gains from immigration accruing to natives. In that article we further showed, using both estimates and anecdotal evidence, that within the US foreign-born workers choose different occupation, have different abilities, and bring different skills to production than those of natives (for a given level of schooling). Think, for instance, of a Chinese born cook or of an Italian born stylist living in the United States: they certainly have abilities and produce services that can not be perfectly substituted by their US-born counterparts. We also showed that substitutability between home and foreign-born workers is particularly low within the group of highly educated workers, where talent, originality, and creativity are important

attributes shaped by culture. In the US most of the highly educated foreign-born 
residents work in the fields of science, technology and engineering, while natives are disproportionately employed in administration, law and education. As an extreme example, think how hard it would have been to substitute for natives that talented group of European born physicists (Albert Einstein, Enrico Fermi et al.) who operated in the US during World War II, or the many Russian mathematicians who migrated to the US during the nineties, or the Indian computer engineers that currently reside in Silicon Valley. They all brought talents complementary and very valuable to the US economy.

These considerations have two implications for our previous calculations. First, because these complementarities exist not only between particular groups but all groups, the host economy may increase the aggregate/average wage of its native workers from an influx of migrants (while single groups can still suffer from a wage decrease). Second, because these complementarities particularly characterize creative, technological and scientific professions, attracting the highest educated foreigners will have the most beneficial effects on domestic productivity (wages). An easy way to incorporate these assumptions in our model is to consider the supply of each type of labor ( $\mathrm{L}_{\mathrm{k}, \mathrm{i}}$ in equation 3 ) as a CES composite itself, made up of home and foreign born workers, as follows:

$$
L_{k, i}=\left[\left(\frac{H_{k, i}}{\tau_{H k}}\right)^{\frac{\theta_{k}-1}{\theta_{k}}}+\left(\frac{F_{k, i}}{\tau_{F k}}\right)^{\frac{\theta_{k}-1}{\theta_{k}}}\right]^{\frac{\theta_{k}}{\theta_{k}-1}} \text { for k= Low, Medium, High }
$$

$1 / \tau_{\mathrm{j}, \mathrm{k}}$ are the efficiency factors of each group and the parameters $\theta_{\mathrm{k}}$ is the elasticity of substitution between the home and foreign born in education group $\mathrm{k}$. Based on the estimates in Ottaviano and Peri (2005) we choose that elasticity to equal 7 for the group with Low schooling, 10 for the group with intermediate schooling and 4 for the group with high schooling. As argued above these estimates imply that the group of highly educated workers benefit to a larger extent from the complementarities of its members. These values were estimated using U.S. census data for the period 1970-2000. Table 7B (the lower panel of Table 7) reports the simulated effects of the stock of immigrants on the wages of natives under these assumptions. Looking first at the immigration 
countries, the group of natives of largest size is still the one that gains the most from immigration. Highly educated natives however now always gain, thanks to stronger complementarities with foreigners in the group. Finally the average wage gains are positive and large. The positive average effect is actually larger when the overall capacity of attracting immigrants, particularly the most educated ones, is larger. Australia enjoys an average increase of native wages by $5.5 \%$, Canada by $4 \%$ and the US by $2.4 \%$. The group of highly educated domestic workers in Australia gains 5.6\% in its wage and in the US the same group increases its wage by $4.3 \%$. Even in the EU15 (last row) the increase in immigrants now has a positive wage effect on each of the native education groups as well as on the average $(+0.8 \%)$. However these effects are much smaller than for the other economies and the largest group (less educated) still experiences the smallest benefit $(+0.5 \%)$.

\section{Conclusions}

The European Union is increasingly becoming an immigration economy. Therefore it is instructive to compare it to those economies that have attracted immigrants for a long time. Produced at a time when important policy discussions about reforming and unifying immigration laws across EU countries are being held, this paper provides a few facts that we believe should be carefully considered. First, the EU has not succeeded in increasing the internal mobility of its workers, not even the most educated ones. Rigid labor, housing and credit markets, along with insider privilege and entitlements for citizens to government transfers (hard to carry across countries) may be responsible for this immobility. Certainly, if Western Europe is to become a society that aims at being inclusive and multicultural, it should first achieve greater internal integration. Second, the EU is still far from attracting talented and educated foreign born at the rate that the US does. Alarmingly in net terms the EU was still experiencing a drain of its highly educated individuals in the year 2000, which possibly has worsened in the last few years. Third, the composition of immigrants in the EU by schooling levels is more likely to penalize the earnings of the largest group of EU natives (still represented in the year 2000 by those with primary education only) while in most 
immigration economies the wages of the majority of workers grow from immigration. Some indications have emerged that the UK is probably the most successful large EU country in attracting foreign talent and selecting foreign-born by education. If the large immigration economies (the US, Canada, Australia and Switzerland) are to be taken as a benchmark model, however, deep changes are needed to make immigration in the EU more similar to theirs in quality and quantity. 


\section{References}

Altonji, J. J. and Card D. (1991) "The effects of Immigration on the Labor Market Outcomes of Less-Skilled Natives "in John M. Abowd and Richard Freeman editions, Immigration, Trade and the Labor Market, Chicago, the University of Chicago Press.

Angrist J. and A. Kugler (2003) "Protective or Counter-Productive? Labor Market Institutions and the Effect of Immigration on EU natives”, Economic Journal, Vol. 113, 302-331.

Baker, M. and Benjamin, D. (1994), "The Performance of Immigrants in the Canadian Labor Market," Journal of Labor Economics, Vol. 12: 455-71.

Barro, Robert J. and Lee J.W. (2000), "International Data on Educational Attainment: Updates and Implications," manuscript, Harvard University, February 2000.

Bhagwati J., A. Panagariya and T. N. Srinivasan (2004) “The Muddles over Outsourcing “ Journal of Economic Perspectives, Vol. 18 (4), 93-114.

Bils, M. and Klenow, P. (2001), “Does Schooling Cause Growth?” American Economic Review, 90 (5), pp. 1160-1183.

Borjas, G. J., (1987), "Self-selection and the Earnings of Immigrants”, American Economic Review, 77 (4), 531-553.

Borjas, G. J. (1991), "Immigration and Self-Selection”, in John Abowd and Richard Freeman, eds., Immigration, Trade and the Labor Market. Chicago, University of Chicago Press, pp. 29-76.

Borjas G. J. (1999) "Heaven's Door" Princeton University Press, Princeton and Oxford, 1999.

Borjas G. J. (2003) "The Labor Demand Curve is Downward Sloping: Reexamining the Impact of Immigration on the Labor Market" Quarterly Journal of Economics, Vol. CXVIII (4), 1335-1374.

Borjas G. J., R. Freeman and L. Katz (1997) "How Much do Immigration and Trade Affect Labor Market Outcomes?" Brookings Papers on Economic Activity, 1997 (1), 1-90

Butcher K. and D. Card (1991) "Immigration and Wages: Evidence from the 1980's" American Economic Review, Papers and Proceedings, 81 (2) 292-296. 
Caselli F. and Coleman W. (2005) “The World Technology Frontier,” manuscript London School of Economics, April 2005.

Card D. (1990) The Impact of the Mariel Boatlift on the Miami Labor Market" Industrial and Labor Relation Review, XLIII, 245-257.

Card D. (2001) "Immigrant Inflows, Native Outflows, and the Local labor Market Impacts of Higher Immigration" Journal of Labor Economics, XIX (2001), 22-64.

Ciccone A. and Peri G. (2005) "Long-Run Substitutability between More and Less Educated Workers: Evidence from U.S. States 1950-1990" Review of Economics and Statistic, Vol. 87, Issue 4, - November 2005.

Clark X., Hatton T.J. and Williamson J.G. (2002) "Where do U.S. Immigrants come from and why?” NBER Working Paper n. 8998.

EEAG (2003), "Report on the European Economy 2003”, European Economic Advisory Group (EEAG) at CESifo, Munich.

Feenstra R. (2003) "Advanced International Trade: Theory and Evidence," Princeton University Press, Princeton, NJ.

Glick, R. and Rose, A. (2002) : "Does a currency union affect trade? The time-series evidence”, European Economic Review, 46(6):1125-1151.

Grossman, J. B. (1982) "The Substitutability of Natives and Immigrants in Production" Review of Economics and Statistics, 64, 596-603.

Hall R. and Jones C. (1999) "Why Do Some Countries Produce So Much More Output per Worker than Others?" Quarterly Journal of Economics, February 1999, 114 (1), 83-116.

Hatton T.J. and Williamson J.G. (2002) “What Fundamentals Drive World Migration?” NBER Working Paper n. 9159.

Hatton T.J. and Williamson J.G. (2004) "International Migration in the Long Run: Positive Selection, Negative Selection and Policy” NBER Working Paper n. 10529.

Helliwell, J. F. (1998). “How Much Do National Borders Matter?”, Chapter 5, pages 79-91. Brookings Institution Press.

Jones C. (2002), "Sources of U.S. Economic Growth in a World of Ideas” American Economic Review 92, pp..220-239. 
Katz, L. and Murphy, K. (1992) "Change in Relative Wages 1963-1987: Supply and Demand Factors," Quarterly Journal of Economics 107, 35-78.

Karemera, D., Oguledo, V. I., and Davis, B. (2000). “A gravity model analysis of international migration to North America”. Applied Economics, 32(13):17451755.

Massey D.S., Arango J., Hugo G., Kouaouachi A., Pellegrino A., Taylor J.E (1993) “Theories of International Migration: A Review and Appraisal” Population and Development Review, 19 (3), 431-466.

Mayda A. M. (2005) “International Migration: A Panel Data Analysis of Economic and non-Economic Determinants” manuscript, Georgetown University, May 2005.

OECD (2005) “Public Data Files of the OECD Project on the stock of international Migrants” Organization for Economic Cooperation and Development, May 2005.

Ottaviano G. and Peri G. (2005) "Rethinking the Gains from Immigration: Theory and Evidence from the US” NBER Working Paper \#11672.

Ortega F. (2004) “Immigration Policies and Skill upgrading”, mimeo Universitat Pompeu Fabra.

Samuleson P. (2004) "Why Ricardo and Mill Rebut and Confirm Arguments of Mainstream Economists Supporting Globalization” in the Journal of Economic Perspectives, Vol. 18 (3) 135-146.

Stiglitz J. (2002) “Globalization and Its Discontents”, W.W. Norton \& Company, June 2002.

Zlotnick H. (1998) “International Migrations 1965-96: an Overview” Population and Development Review, 24 (3) 429-468. 
Table 1: Stock of Immigrants and Emigrants in OECD countries. Census 2000, population aged 15 years and older.

\begin{tabular}{|c|c|c|c|}
\hline COUNTRY & $\begin{array}{c}1 \\
\text { net immigrant stock } \\
\text { as share of total } \\
\text { natives }\end{array}$ & $\begin{array}{c}2 \\
\text { Stock of } \\
\text { Foreign-born as } \\
\text { share of } \\
\text { residents }\end{array}$ & $\begin{array}{c}3 \\
\text { Stock of } \\
\text { residents abroad } \\
\text { as share of total } \\
\text { born }\end{array}$ \\
\hline Luxembourg & 0.358 & 0.326 & 0.112 \\
\hline Australia & 0.275 & 0.230 & 0.024 \\
\hline Switzerland & 0.230 & 0.224 & 0.055 \\
\hline Canada & 0.191 & 0.193 & 0.046 \\
\hline USA & 0.135 & 0.123 & 0.005 \\
\hline Sweden & 0.107 & 0.120 & 0.029 \\
\hline Austria & 0.091 & 0.125 & 0.049 \\
\hline France & 0.090 & 0.100 & 0.021 \\
\hline Germany & 0.087 & 0.121 & 0.048 \\
\hline New Zealand & 0.081 & 0.195 & 0.138 \\
\hline Belgium & 0.080 & 0.107 & 0.038 \\
\hline The Netherlands & 0.067 & 0.101 & 0.043 \\
\hline EU15 ${ }^{a}$ & 0.047 & 0.072 & 0.030 \\
\hline Norway & 0.045 & 0.073 & 0.033 \\
\hline Greece & 0.039 & 0.103 & 0.071 \\
\hline Spain & 0.036 & 0.053 & 0.020 \\
\hline Denmark & 0.034 & 0.068 & 0.037 \\
\hline U.K. & 0.027 & 0.083 & 0.060 \\
\hline Japan & 0.005 & 0.010 & 0.005 \\
\hline Hungary & -0.004 & 0.029 & 0.032 \\
\hline South Korea & -0.005 & 0.003 & 0.008 \\
\hline Turkey & -0.013 & 0.019 & 0.031 \\
\hline Poland & -0.015 & 0.021 & 0.034 \\
\hline Finland & -0.032 & 0.025 & 0.055 \\
\hline Portugal & -0.069 & 0.063 & 0.119 \\
\hline Mexico & -0.094 & 0.005 & 0.090 \\
\hline Ireland & -0.121 & 0.104 & 0.191 \\
\hline
\end{tabular}

Source: Author's calculations on OECD (2005) data set a: Excluding Italy for which data on country of birth of residents are not available. 


\section{Table 2: Net stock of immigrants by education level Census 2000, age 15 and older}

\begin{tabular}{|c|c|c|c|}
\hline $\begin{array}{l}\text { 2A: NET I } \\
\text { country }\end{array}$ & $\begin{array}{l}\text { MIGRANT STOCK, TERT } \\
\text { net immigrant stock } \\
\text { as share of total resident }\end{array}$ & $\begin{array}{l}\text { RY EDUCATIOI } \\
\text { net immigrant } \\
\text { stock }\end{array}$ & $\begin{array}{l}\text { Total } \\
\text { residents }\end{array}$ \\
\hline Australia & 0.361 & 1345326 & 5076425 \\
\hline Canada & 0.257 & 1610587 & 7867545 \\
\hline Switzerland & 0.226 & 184061 & 1000155 \\
\hline USA & 0.152 & 7803770 & 59187830 \\
\hline EU15 & -0.001 & -62617.71874 & 43980128 \\
\hline
\end{tabular}

\begin{tabular}{|c|c|c|c|}
\hline \multicolumn{4}{|c|}{$\begin{array}{c}\text { 2B: NET IMMIGRANT STOCK, SECONDARY EDUCATION } \\
\text { net immigrant stock }\end{array}$} \\
\hline Australia & 0.350 & 739139 & 2110946 \\
\hline Canada & 0.178 & 1519130 & 8556870 \\
\hline Switzerland & 0.132 & 351938 & 2657729 \\
\hline USA & 0.110 & 11819336 & 107889714 \\
\hline EU15 & 0.006 & 551853 & 86310119 \\
\hline
\end{tabular}

\begin{tabular}{|lrrr|}
\hline 2C: NET IMMIGRANT STOCK , PRIMARY EDUCATION \\
$\begin{array}{l}\text { net immigrant stock } \\
\text { country }\end{array}$ & $\begin{array}{l}\text { net immigrant } \\
\text { as share of total resident }\end{array}$ & stock & Total residents \\
\hline Switzerland & 0.385 & 419608 & 1090638 \\
USA & 0.300 & 12474002 & 41597025 \\
Australia & 0.293 & 1268208 & 4324802 \\
Canada & 0.234 & 1419656 & 6057084 \\
EU15 & 0.034 & 3574683 & 104822511 \\
\hline
\end{tabular}

Source: Author's Calculations on OECD (2005) data. 
Table 3: Geographic Determinants of bilateral migration

\begin{tabular}{|c|c|c|c|c|}
\hline $\begin{array}{c}\text { Dependent. } \\
\text { Variable: } \\
\text { Ln(stock } \\
\text { migrants) }\end{array}$ & $\begin{array}{l}\text { I: } \\
\text { All Groups }\end{array}$ & $\begin{array}{c}\text { II: } \\
\text { Tertiary } \\
\text { Education } \\
\text { only } \\
\text { (16 yrs }+ \text { ) }\end{array}$ & $\begin{array}{c}\text { III: } \\
\text { Secondary } \\
\text { Education } \\
\text { Only } \\
\text { (12-16 yrs) }\end{array}$ & $\begin{array}{c}\text { IV: } \\
\text { Primary } \\
\text { Education } \\
\text { Only } \\
\text { (0-11 yrs) }\end{array}$ \\
\hline Ln(distance) & $\begin{array}{c}-1.29 * * \\
(0.09)\end{array}$ & $\begin{array}{c}-1.21^{* *} \\
(0.15)\end{array}$ & $\begin{array}{c}-1.39 * * \\
(0.16)\end{array}$ & $\begin{array}{c}-1.27^{* *} \\
(0.17)\end{array}$ \\
\hline Common Border & $\begin{array}{l}0.74 * * \\
(0.21)\end{array}$ & $\begin{array}{c}0.41 \\
(0.34)\end{array}$ & $\begin{array}{c}0.59 \\
(0.36)\end{array}$ & $\begin{array}{l}1.21 * * \\
(0.39)\end{array}$ \\
\hline Common & $0.45 * *$ & $0.47 *$ & 0.45 & 0.42 \\
\hline Language & (0.15) & $(0.22)$ & $(0.27)$ & $(0.29)$ \\
\hline Trade Agreement & $\begin{array}{l}0.20^{*} \\
(0.11)\end{array}$ & $\begin{array}{c}0.17 \\
(0.17)\end{array}$ & $\begin{array}{c}0.18 \\
(0.19)\end{array}$ & $\begin{array}{c}0.28 \\
(0.21)\end{array}$ \\
\hline Within EU & $\begin{array}{l}-0.02 \\
(0.10)\end{array}$ & $\begin{array}{c}0.13 \\
(0.12)\end{array}$ & $\begin{array}{l}-0.10 \\
(0.24)\end{array}$ & $\begin{array}{l}-0.20 \\
(0.26)\end{array}$ \\
\hline $\begin{array}{l}\text { Country of } \\
\text { Origin Effect }\end{array}$ & Yes & Yes & Yes & Yes \\
\hline $\begin{array}{c}\text { Country of } \\
\text { Destination } \\
\text { Effect }\end{array}$ & Yes & Yes & Yes & Yes \\
\hline $\begin{array}{l}\text { Tertiary } \\
\text { Education } \\
\text { Dummy }\end{array}$ & $\begin{array}{c}0.43^{* *} \\
(0.08)\end{array}$ & n.a. & n.a. & n.a. \\
\hline $\begin{array}{l}\text { Secondary } \\
\text { Education } \\
\text { Dummy }\end{array}$ & $\begin{array}{l}0.42 * * \\
(0.08)\end{array}$ & n.a. & n.a. & n.a. \\
\hline Observations & 2268 & 756 & 756 & 756 \\
\hline $\mathrm{R}^{2}$ & 0.71 & 0.76 & 0.74 & 0.72 \\
\hline
\end{tabular}

Notes: Dependent Variable: natural logarithm of the total stock of emigrants in each schooling group in year 2000. The zero values (only $2 \%$ of the total) have been substituted with ones.

Number of countries is 28. Each one has 27 observations on gross emigrants. Education groups are 3.

Specification I: People 15 years of age and older, all schooling groups pooled Specification II: Only people 15 years and older with some tertiary education. Specification III: Only people 15 years and older with some secondary education Specification IV: Only people 15 years and older with some tertiary education Standard Errors are clustered by country couple $*=$ significant at $5 \%, * *=$ significant at $10 \%$. 
Table 4: Geographic and Economic Determinants of bilateral migration

\begin{tabular}{|c|c|c|c|c|}
\hline $\begin{array}{c}\text { Dependent } \\
\text { Variable } \\
\text { Ln(stock migrants) }\end{array}$ & $\begin{array}{c}\text { I: } \\
\text { All groups }\end{array}$ & $\begin{array}{c}\text { II: } \\
\text { Tertiary } \\
\text { education } \\
\text { only } \\
(16 \text { yrs }+) \\
\end{array}$ & $\begin{array}{c}\text { III: } \\
\text { Secondary } \\
\text { Education } \\
\text { Only } \\
\text { (12-16 yrs) }\end{array}$ & $\begin{array}{c}\text { IV: } \\
\text { Primary } \\
\text { Education } \\
\text { Only } \\
(0-11 \text { yrs }) \\
\end{array}$ \\
\hline Ln(distance) & $\begin{array}{c}-0.77^{* *} \\
(0.10)\end{array}$ & $\begin{array}{c}-0.78^{* *} \\
(0.19)\end{array}$ & $\begin{array}{c}-0.74^{* *} \\
(0.18)\end{array}$ & $\begin{array}{c}-0.89 * * \\
(0.19)\end{array}$ \\
\hline Common Border & $\begin{array}{l}0.63^{* *} \\
(0.29)\end{array}$ & $\begin{array}{c}0.20 \\
(0.45)\end{array}$ & $\begin{array}{l}0.41^{* *} \\
(0.50)\end{array}$ & $\begin{array}{l}1.08 * * \\
(0.50)\end{array}$ \\
\hline Common Language & $\begin{array}{l}1.83 * * \\
(0.21)\end{array}$ & $\begin{array}{l}2.20 * * \\
(0.35)\end{array}$ & $\begin{array}{l}1.79 * * \\
(0.39)\end{array}$ & $\begin{array}{l}1.12 * * \\
(0.34)\end{array}$ \\
\hline Trade Agreement & $\begin{array}{l}1.03^{*} \\
(0.24)\end{array}$ & $\begin{array}{l}0.93^{*} \\
(0.40)\end{array}$ & $\begin{array}{l}1.22^{* *} \\
(0.40)\end{array}$ & $\begin{array}{l}0.95 * * \\
(0.44)\end{array}$ \\
\hline Within EU & $\begin{array}{c}-1.20^{* *} \\
(0.27)\end{array}$ & $\begin{array}{l}-0.89 \\
(0.47)\end{array}$ & $\begin{array}{c}-1.17^{* *} \\
(0.49)\end{array}$ & $\begin{array}{c}-1.94 * * \\
(0.50)\end{array}$ \\
\hline $\begin{array}{l}\text { Ln(individual wage) } \\
\text { destination }\end{array}$ & $\begin{array}{l}2.92 * * \\
(0.20)\end{array}$ & $\begin{array}{l}1.81^{* *} \\
(0.27)\end{array}$ & $\begin{array}{l}3.11^{* *} \\
(0.41)\end{array}$ & $\begin{array}{l}5.84^{*} \\
(0.46)\end{array}$ \\
\hline $\begin{array}{l}\text { Ln(individual wage) } \\
\text { origin }\end{array}$ & $\begin{array}{c}0.40 \\
(0.24)\end{array}$ & $\begin{array}{l}-0.34 \\
(0.40)\end{array}$ & $\begin{array}{c}0.54 \\
(0.40)\end{array}$ & $\begin{array}{c}0.93 \\
(0.50)\end{array}$ \\
\hline $\begin{array}{l}\text { Ln(population) } \\
\text { destination }\end{array}$ & $\begin{array}{l}0.66^{* *} \\
(0.06)\end{array}$ & $\begin{array}{l}0.61^{* *} \\
(0.11)\end{array}$ & $\begin{array}{l}0.62^{* *} \\
(0.12)\end{array}$ & $\begin{array}{l}1.46^{* *} \\
(0.13)\end{array}$ \\
\hline $\begin{array}{l}\mathrm{Ln} \text { (population) } \\
\text { origin }\end{array}$ & $\begin{array}{l}0.77^{* *} \\
(0.06)\end{array}$ & $\begin{array}{l}0.83^{* *} \\
(0.11)\end{array}$ & $\begin{array}{l}0.77 * * \\
(0.11)\end{array}$ & $\begin{array}{l}1.09 * * \\
(0.13)\end{array}$ \\
\hline $\begin{array}{l}\text { Tertiary Education } \\
\text { Dummy }\end{array}$ & $\begin{array}{l}1.32 * * \\
(0.28)\end{array}$ & n.a. & n.a. & n.a. \\
\hline $\begin{array}{l}\text { Secondary } \\
\text { Education Dummy }\end{array}$ & $\begin{array}{l}1.32 * * \\
(0.36)\end{array}$ & n.a. & n.a. & n.a. \\
\hline Observations & 918 & 306 & 306 & 306 \\
\hline$\overline{\mathrm{R}^{2}}$ & 0.35 & 0.34 & 0.32 & 0.31 \\
\hline
\end{tabular}

Notes: Dependent Variable: natural logarithm of the total stock of emigrants in each schooling group in year 2000. The zero values (only $2 \%$ of the total) have been substituted with ones.

The explanatory variables Ln(individual wage) are imputed for each education group as described in the main text.

Number of countries is18. Each one has 17 observations on gross emigrants. Education groups are 3.

Specification I: People 15 years of age and older, all schooling groups pooled Specification II: Only people 15 years and older with some tertiary education. Specification III: Only people 15 years and older with some secondary education Specification IV: Only people 15 years and older with some tertiary education Standard Errors are clustered by country couple $*=$ significant at $5 \%, * *=$ significant at $10 \%$. 
Table 5: Attraction of highly educated international migrants: US and EU unexplained effects

\begin{tabular}{ccccc}
\hline $\begin{array}{c}\text { Destination- } \\
\text { country effects, } \\
\text { Highly educated } \\
\text { migrants }\end{array}$ & $\begin{array}{c}\text { I } \\
\text { Baseline }\end{array}$ & $\begin{array}{c}\text { II } \\
\text { Including } \\
\text { Canada and } \\
\text { Australia }\end{array}$ & $\begin{array}{c}\text { III } \\
\text { Controlling } \\
\text { for country } \\
\text { of origin } \\
\text { effects }\end{array}$ & $\begin{array}{c}\text { IV } \\
\text { Specific for } \\
\text { Germany } \\
\text { and UK }\end{array}$ \\
\hline EU & $-1.65^{* *}$ & $-0.58^{* *}$ & $-1.44^{* *}$ & \\
Germany & $(0.36)$ & $(0.34)$ & $(0.26)$ & 0.04 \\
U.K. & & & & $(0.10)$ \\
US & & & & $+2.79^{* *}$ \\
& $+2.73^{* *}$ & $+4.77^{* *}$ & $+3.14^{* *}$ & $+0.56)$ \\
Canada & $(0.59)$ & $(0.59)$ & $(0.48)$ & $(0.69)$ \\
& & $+3.88^{* *}$ & & $+4.58^{* *}$ \\
Australia & & $(0.44)$ & & $(0.54)$ \\
& & $+4.38^{* *}$ & & $+4.89^{* *}$ \\
Observations & 306 & $(0.53)$ & 306 & $30.50)$ \\
\hline $\mathrm{R}^{2}$ & 0.42 & 0.54 & 0.46 & 0.57 \\
\hline
\end{tabular}

Notes: The dependent variable is Ln(stock of migrants).

The values reported in each column are the estimated coefficients and standard errors for dummies specific to a country (or area) of origin of the emigrants, in a regression as specification II in Table 5.

The coefficient captures the excess capacity of attraction of highly educated migrants (if positive) or the disadvantage in attracting immigrants (if negative) of a country, after we control for the economic and geographic determinants of migration (such as wages population, distance and barriers).

$*=$ significant at $5 \%, * *=$ significant at $10 \%$. 
Table 6: Education of Natives and Education of Immigrants

\begin{tabular}{|c|c|c|c|}
\hline \multicolumn{4}{|c|}{$\begin{array}{l}\text { 6A: } \\
\text { distribution of native born across education groups }\end{array}$} \\
\hline & low & medium & high \\
\hline Australia & 0.450 & 0.163 & 0.388 \\
\hline Canada & 0.309 & 0.371 & 0.320 \\
\hline Switzerland & 0.256 & 0.552 & 0.192 \\
\hline USA & 0.219 & 0.511 & 0.270 \\
\hline EU15 & 0.535 & 0.232 & 0.232 \\
\hline France & 0.548 & 0.272 & 0.181 \\
\hline Germany & 0.236 & 0.570 & 0.194 \\
\hline UK & 0.512 & 0.287 & 0.201 \\
\hline
\end{tabular}

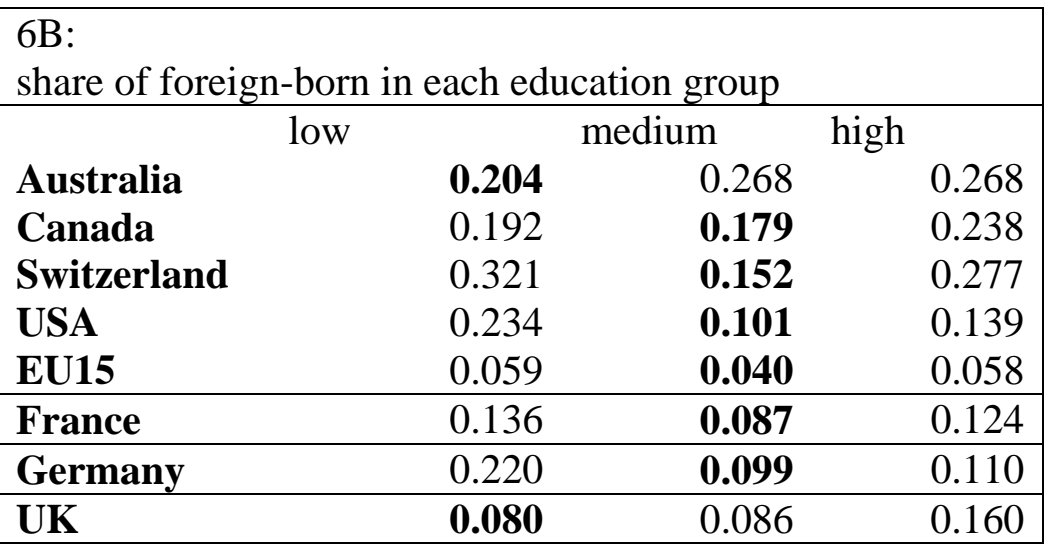

Source: Author's Calculations on OECD (2005) data relative to foreign-born in year 2000 and Barro and Lee (2000) data relative to education of all residents in year 1999. 

Table 7: Calculated impact of the stock of immigrants (2000) on Wages of different
educational groups of natives

7A: Assuming perfect substitutability between native and migrants in the same education group

\begin{tabular}{|l|c|c|c|c|}
\hline & Low & Intermediate & High & Average \\
\hline AUS & $+\mathbf{3 . 7 \%}$ & $-2.4 \%$ & $-3.2 \%$ & $0.02 \%$ \\
\hline CAN & $+1.4 \%$ & $+\mathbf{2 . 0} \%$ & $-3.7 \%$ & $0 \%$ \\
\hline CHE & $-11.2 \%$ & $+\mathbf{7 . 1 \%}$ & $-5.1 \%$ & $0.1 \%$ \\
\hline USA & $-8.4 \%$ & $+3.4 \%$ & $+0.4 \%$ & $0.05 \%$ \\
\hline EU15 & $-0.3 \%$ & $+1 \%$ & $-0.2 \%$ & $-0.05 \%$ \\
\hline
\end{tabular}

7B: Using the estimates of substitutability between natives and migrants in the same schooling group as in Ottaviano and Peri (2005)

\begin{tabular}{|l|c|c|c|c|}
\hline & Low & Intermediate & High & Average \\
\hline AUS & $+\mathbf{7 . 3 \%}$ & $+0.9 \%$ & $+5.6 \%$ & $+5.5 \%$ \\
\hline CAN & $+4.6 \%$ & $+\mathbf{4 . 1 \%}$ & $+3.7 \%$ & $+4.0 \%$ \\
\hline CHE & $-4.8 \%$ & $\mathbf{+ 8 . 8 \%}$ & +3.8 & $+4.3 \%$ \\
\hline USA & $-4.3 \%$ & $+\mathbf{4 . 5 \%}$ & $+4.2 \%$ & $+2.4 \%$ \\
\hline EU15 & +0.5 & $+1.4 \%$ & $+1.2 \%$ & $+0.8 \%$ \\
\hline
\end{tabular}

The effects have been calculated by assuming a CES production function with elasticity of substitution between schooling groups of 1.5. The shares of native and foreign-born in each education group were taken from the census 2000, the share of total wage to each group has been calculated using the returns to schooling reported in Bils and Klenow (2000) and the procedure described in the text. The returns to schooling used are:

Australia: $6.4 \%$ per year of schooling

Canada: $4.2 \%$

Switzerland: $7.2 \%$

USA: $9.3 \%$

EU15 (Germany): 7.7\% 
Figure 1: Stock of immigrants in the EU countries, Census 2000, population 15 years and older

\section{Share of foreign-born in EU countries}

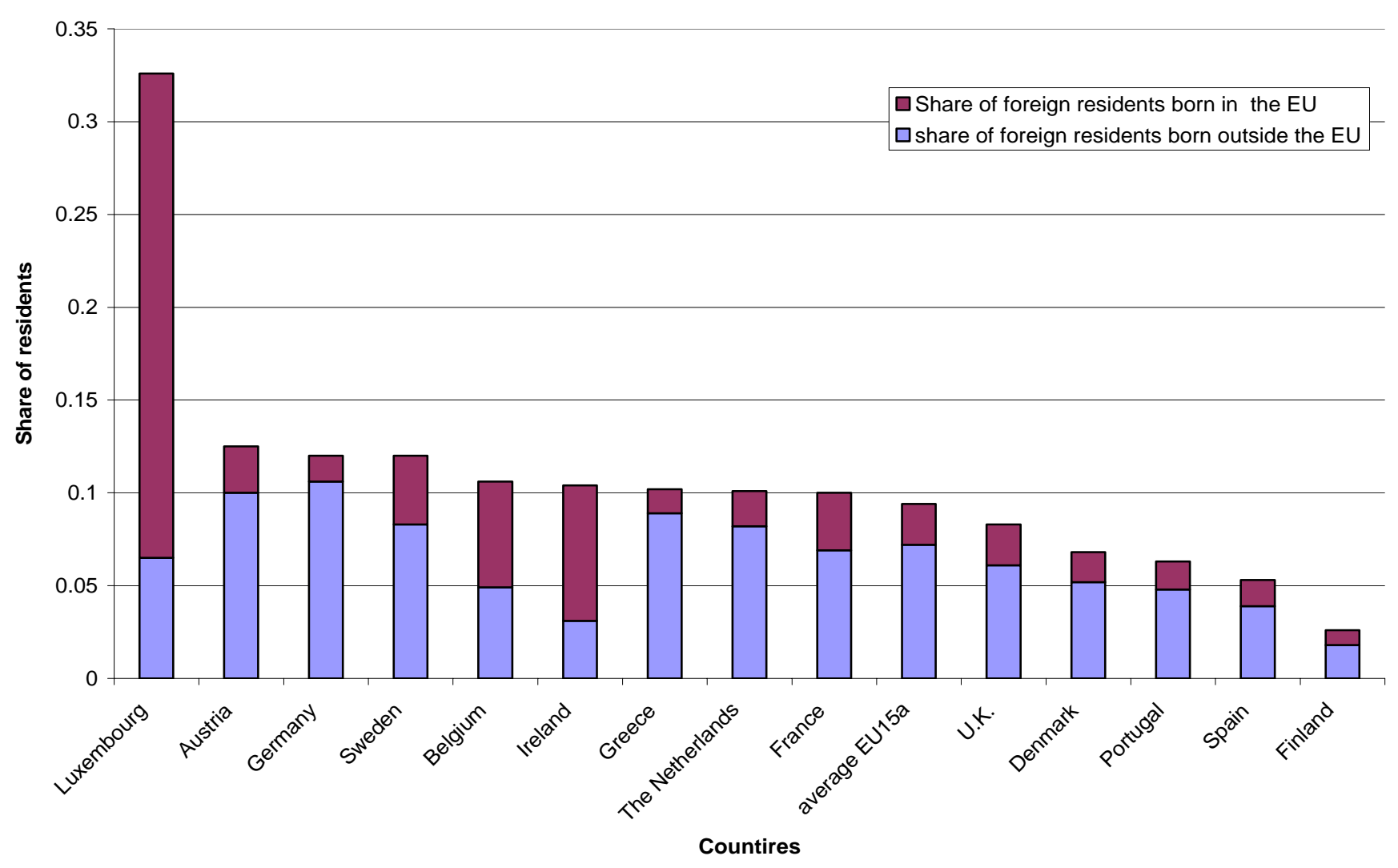

Source: Author's Calculations on OECD (2005) data.

a: Excluding Italy for which data on country of birth of residents are not available. 
Figure 2 (Panel)

Education of Natives and Education of Immigrants: distribution across 3 schooling groups
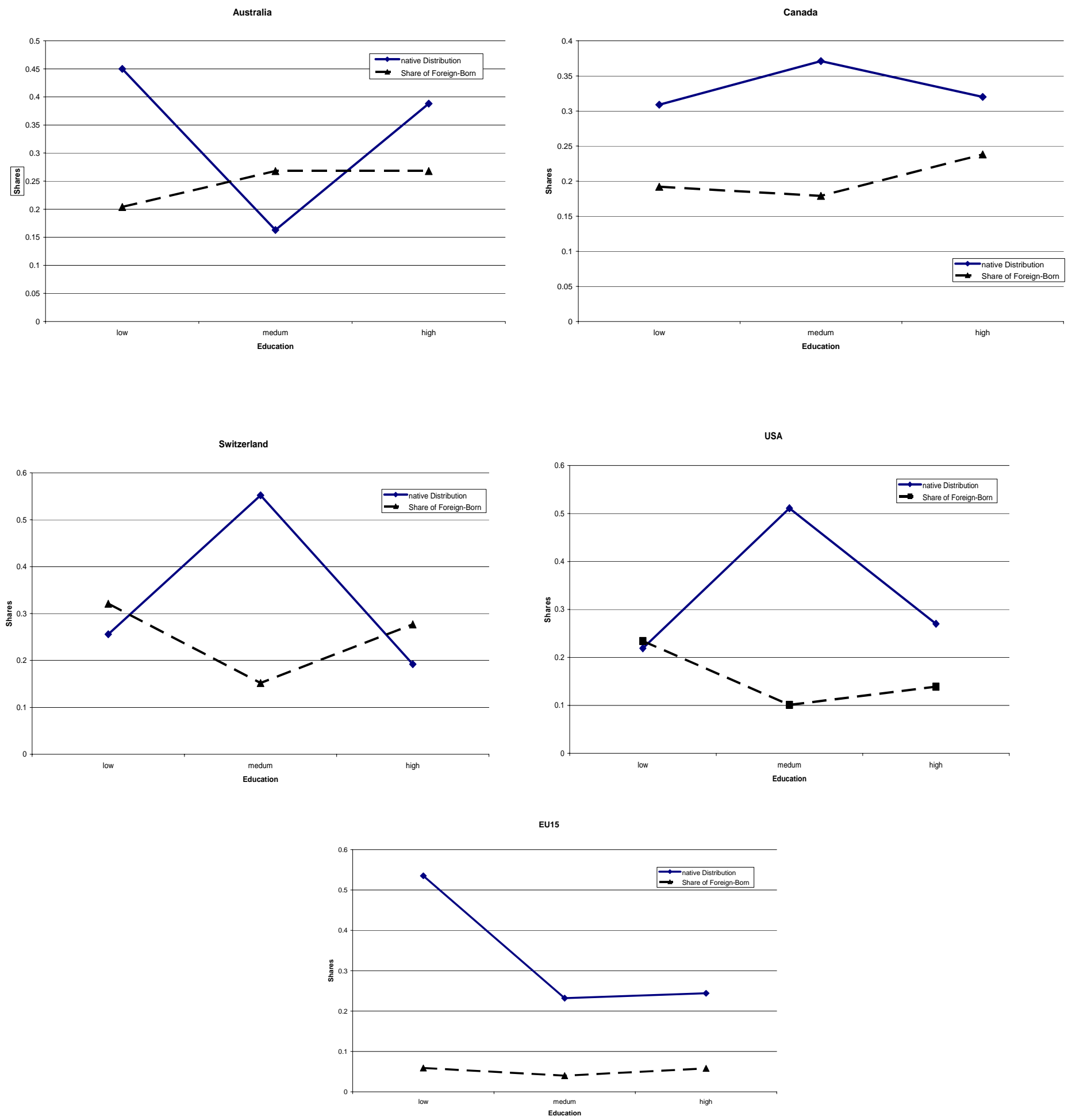